\title{
A Microfluidic Cell Stretch Device to Investigate the Effects of Stretching Stress on Artery Smooth Muscle Cell Proliferation in Pulmonary Arterial Hypertension
}

\author{
Kae Sato ${ }^{1, *}$, Manami Nitta ${ }^{1}$ and Aiko Ogawa ${ }^{2}$ \\ 1 Department of Chemical and Biological Sciences, Faculty of Science, Japan Women's University, \\ 2-8-1 Mejirodai, Bunkyo, Tokyo 112-8681, Japan \\ 2 Division of Molecular and Cellular Medicine, Department of Clinical Science, National Hospital \\ Organization Okayama Medical Center, 1711-1 Tamasu, Kita, Okayama 701-1192, Japan; \\ aiko-oky@umin.ac.jp \\ * Correspondence: satouk@fc.jwu.ac.jp
}

Received: 27 November 2018; Accepted: 21 December 2018; Published: 26 December 2018

\begin{abstract}
A microfluidic cell stretch device was developed to investigate the effects of stretching stress on pulmonary artery smooth muscle cell (PASMC) proliferation in pulmonary arterial hypertension (PAH). The microfluidic device harbors upper cell culture and lower control channels, separated by a stretchable poly(dimethylsiloxane) membrane that acts as a cell culture substrate. The lower channel inlet was connected to a vacuum pump via a digital switch-controlled solenoid valve. For cyclic stretch at heartbeat frequency $(80 \mathrm{bpm})$, the open or close time for each valve was set to $0.38 \mathrm{~s}$. Proliferation of normal PASMCs and those obtained from patients was enhanced by the circumferential stretching stimulation. This is the first report showing patient cells increased in number by stretching stress. These results are consistent with the abnormal proliferation observed in PAH. Circumferential stretch stress was applied to the cells without increasing the pressure inside the microchannel. Our data may suggest that the stretch stress itself promotes cell proliferation in PAH.
\end{abstract}

Keywords: pulmonary arterial hypertension; smooth muscle cell; microfluidic cell stretch device

\section{Introduction}

Pulmonary arterial hypertension $(\mathrm{PAH})$ is a rare disease characterized by increased pulmonary artery pressure, leading to right heart failure and death [1]. Although the blood vessel closure in PAH is caused by the abnormal proliferation of pulmonary artery smooth muscle cells (PASMCs), endothelial cells (ECs), and fibroblasts, its mechanism is unknown. There is an urgent need to develop novel in vitro models to elucidate this mechanism, because current animal models may not fully represent current clinical observations [2]. We previously reported the first successful isolation of PASMCs from patients, and characterized the cells by immunostaining and quantitative reverse-transcriptase polymerase chain reaction (RT-PCR) techniques [3-5]. However, these cell-based experiments were performed under static culture conditions. Construction of a cell culture microenvironment that mimics the disease, using mechanical stress from fluid flow and stretching, is required to clarify the mechanism.

Recently, microfluidic cell culture platforms mimicking vascular flow or vascular constriction have been developed [6-13]. A microdevice with a stretchable poly(dimethylsiloxane) (PDMS) membrane as a cell culture substrate, to which cyclic stimulation of circumferential strain was added, has been developed for vascular research [14]. Using this device, human mesenchymal stem cells (MSCs) were cultured with continuous cyclic stretch over a period of 7 days, and localization and alignment of the MSCs by the mechanical stretch were observed. Microfluidic flow-stretch devices integrating two 
major mechanical stimulations in the cardiovascular systems, i.e., fluid shear stress and circumferential wall stress (cyclic stretch), have also been reported [15-17]. These microfluidic models mimicked the hemodynamic microenvironment of blood vessels. Imposing a fluid shear stress only, a cyclic stretch only, or both stimulations on rat mesenchymal stem cells or human umbilical vein endothelial cells, it was found that the alignment of the cellular stress fibers varied with the cell and simulation type [15]. Huang et al. [16] reported a microdevice-based tumor extravasation research model with stretch and fluid stimulations. They evaluated the effects of cyclic stretch or fluid shear stress on tumor cell adhesion to an EC monolayer. Van Engeland et al. [17] reported the effects of cyclic stretch or fluid shear stress on both aortic ECs and human aortic vascular smooth muscle cells in a microdevice. Moreover, a compact microfluidic platform for an automated, multimodal assessment of intact small blood vessels has been reported [18]. Mouse olfactory artery segments were reversibly loaded onto the microfluidic device and kept under physiological (i.e., close to in vivo) environmental conditions. This transparent microfluidic device allowed for quantitative calcium fluorescence imaging of intact blood vessels. It is difficult to realize in vivo imaging in a deep part of a living body. Therefore, intact vessels in microfluidics will become an effective experimental tool.

We have reported on microfluidic culture and analysis of PASMCs for the study of pulmonary hypertension [19]. We found that shear stress caused a 7.5-fold increase in the transcription levels of a cell cycle-related molecule, Cyclin D1. We also reported that Japanese PAH patients with high pulse rates had a poor prognosis [20]. We propose that cyclic stretch may increase the severity of the disease. Here, we aimed to develop a cell stretching microdevice to investigate the relationship between blood vessel expansion/contraction and the proliferation of PASMCs in PAH. Generally, cyclic stretch increases the proliferation rate of vascular smooth muscle cells under in vitro conditions. Sheep and rat vascular smooth muscle cells that had been exposed to $20 \%$ cyclic stretch demonstrated increased expression of positive regulators of proliferation, such as hypoxia-inducible factor- $1 \alpha$, vascular endothelial growth factor, and transforming growth factor- $\beta 1$ [21,22].

In this study, PASMCs were cultured in the device with cyclic stretch at the same rate as the patient's heartbeat, and cell proliferation and the transcription levels of molecules related to cell proliferation were analyzed. In the body, circumferential wall stress increases by increasing internal pressure. It is necessary to evaluate the effects of arterial pressure and cell stretch separately, to understand the relative contribution of each to the disease. To investigate whether circumferential stretch stress itself promotes cell proliferation, circumferential stretch stress was applied to cells without increasing the internal microchannel pressure in these experiments. While there are many reports investigating the effects of stretch on the same plane, there are few reports on the effects of circumferential stretch. To mimic the artery, it is important to use a device which can expose cells to cyclic circumferential stretch.

\section{Materials and Methods}

\subsection{Fabrication of a Cell Stretch Device}

A PDMS membrane was fabricated by spin coating of a PDMS prepolymer on a Polymethyl methacrylate (PMMA) substrate (Figure 1a). PDMS prepolymer (SILPOT184W /C; Dow Corning Toray, Tokyo, Japan) was mixed with its curing agent at a mass ratio of 10:1, 15:1, or 20:1. The PDMS mixture $(600 \mu \mathrm{L})$ was degassed and spin-coated on a PMMA sheet $(76 \mathrm{~mm} \times 52 \mathrm{~mm})$ at $500 \mathrm{rpm}$ for $20 \mathrm{~s}$, followed by $2400 \mathrm{rpm}$ for $600 \mathrm{~s}$. The PDMS membrane was then baked at $65^{\circ} \mathrm{C}$ for $1 \mathrm{~h}$.

Microchannels were fabricated by molding as described previously [23,24]. The degassed PDMS mixture was poured to a thickness of $4 \mathrm{~mm}$ (upper sheet) or $1 \mathrm{~mm}$ (lower sheet), with upper $(0.5 \times 1 \times 10 \mathrm{~mm})$ or lower $(0.5 \times 2 \times 15 \mathrm{~mm})$ channel structures, respectively, and baked at $65^{\circ} \mathrm{C}$ for $1 \mathrm{~h}$. The PDMS replica was adhered to a glass slide $(26 \times 76 \mathrm{~mm})$ and baked at $100{ }^{\circ} \mathrm{C}$ for $1 \mathrm{~h}$. Through-holes were made at both ends of the upper microchannel with a $1.0 \mathrm{~mm}$ biopsy punch. 

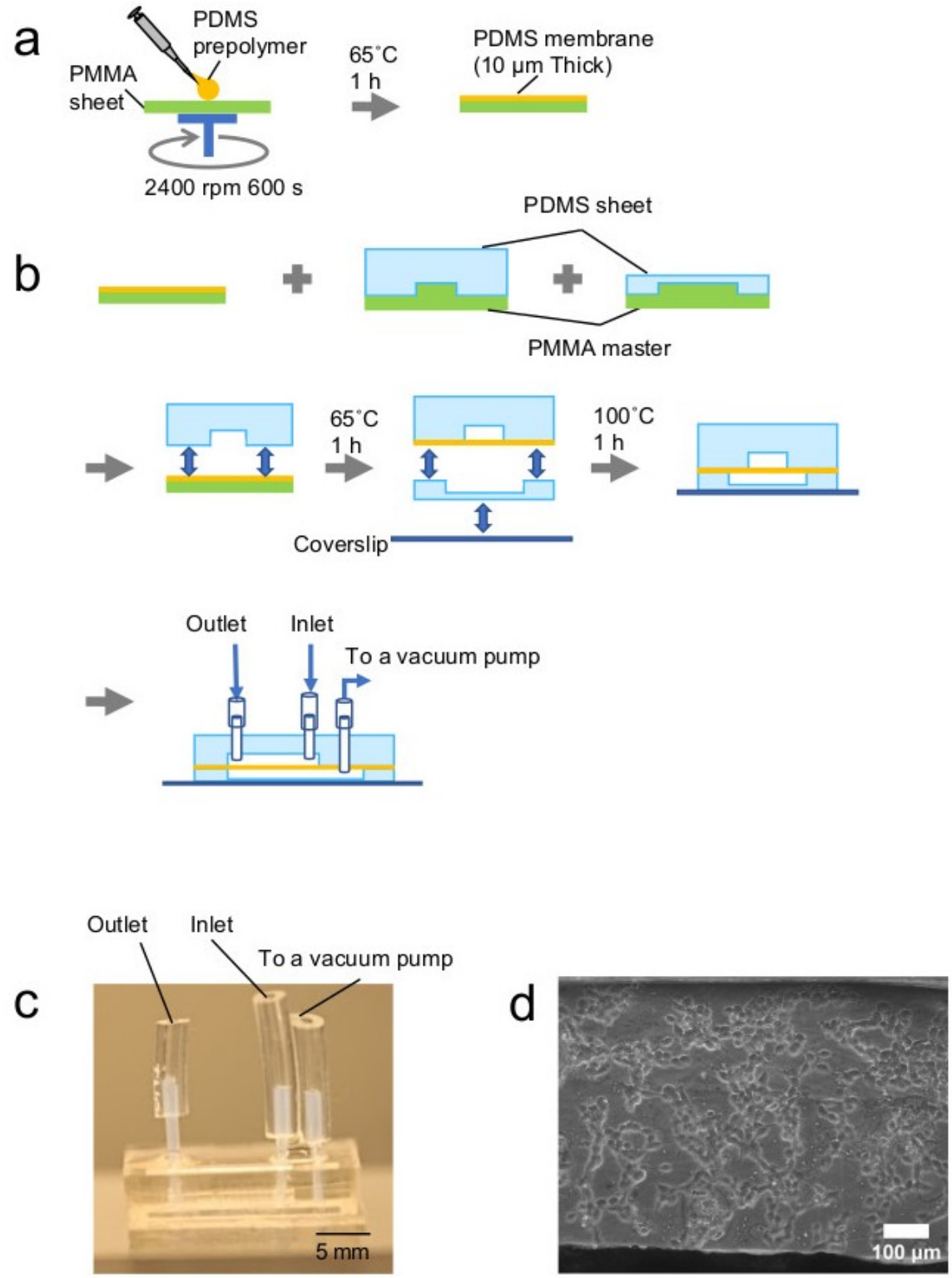

Figure 1. Device fabrication. (a) A poly(dimethylsiloxane) (PDMS) membrane (10 $\mu \mathrm{m}$ thick) was fabricated by spin coating a PDMS prepolymer on a Polymethyl methacrylate (PMMA) substrate.

(b) Illustration of the device assembly and tube connection process. (c) Photograph of the device.

(d) Phase contrast image of normal pulmonary artery smooth muscle cells (PASMCs) in a microchannel.

The fabricated PDMS membrane and sheets were laminated as shown in Figure $1 \mathrm{~b}$. The bonding surfaces of the PDMS membrane on the PMMA substrate and the upper PDMS sheet were exposed to oxygen plasma at $100 \mathrm{~W}$ for $35 \mathrm{~s}$. Then, the PDMS sheet was bonded to the PDMS membrane and baked at $65{ }^{\circ} \mathrm{C}$ for $1 \mathrm{~h}$. Next, the PDMS sheet with the PDMS membrane was removed slowly from the PMMA sheet, and a hole to connect with the lower channel was punched from the membrane side with a $1.0 \mathrm{~mm}$ biopsy punch. The bottom surface of the lower PDMS sheet was bonded to a glass cover slip, and the other surface was bonded to the PDMS membrane with the upper PDMS sheet after plasma treatment and baked at $100{ }^{\circ} \mathrm{C}$ for $1 \mathrm{~h}$. Each hole was connected to a polytetrafluoroethylene (PTFE) tube $(0.46 \mathrm{~mm}$ id, $0.92 \mathrm{~mm}$ od, $10 \mathrm{~mm}$ long; Nichias, Tokyo, Japan). The PTFE tube was glued to the upper sheet with the PDMS mixture and baked at $100{ }^{\circ} \mathrm{C}$ for $1 \mathrm{~h}$. The other end of the PTFE tube was connected to a TYGON tube $(0.79 \mathrm{~mm}$ id, $2.38 \mathrm{~mm}$ od, and $10 \mathrm{~mm}$ (outlet) or $12 \mathrm{~mm}$ (inlet) long; Saint-Gobain K.K., Tokyo, Japan). To confirm whether bonding of the PDMS membrane 
was completed, the device was sliced with a cutter knife and the section observed with a measuring microscope (STM-6, Olympus, Tokyo, Japan) with a $20 \times$ objective lens.

An illustration of a microfluidic cell stretch system is shown in Figure 2a. The free end of the lower channel inlet TYGON tube was connected to a solenoid valve (V100 series, SMC, Tokyo, Japan) via another TYGON tube $(2.0 \mathrm{~mm}$ id, $4.0 \mathrm{~mm}$ od). The solenoid valve was connected to a vacuum pump (EAP-01, As one, Osaka, Japan) with a TYGON tube $(2.0 \mathrm{~mm}$ id, $4.0 \mathrm{~mm}$ od), a different diameter connector, and a vinylic polymer tube $(5.0 \mathrm{~mm}$ id, $8.0 \mathrm{~mm}$ od, As one). The solenoid valve was controlled with a NI9477 digital switch and LabView software (National Instruments; Austin, TX, USA). For cyclic stretch at heartbeat frequency $(80 \mathrm{bpm})$, each valve open or close time was $0.38 \mathrm{~s}$.
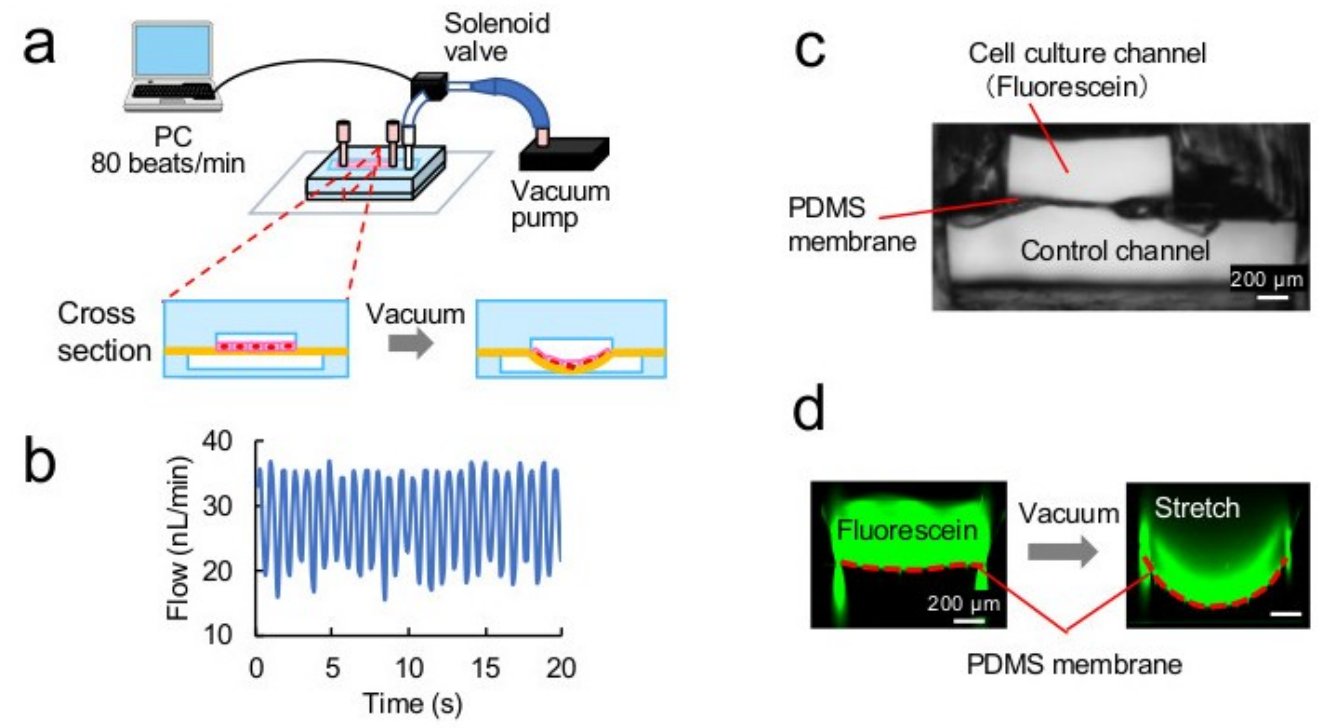

Figure 2. System setup and stretching properties. (a) An illustration of the system. The control channel was connected to a computer-controlled solenoid valve and an air pump. (b) Flow rate at the upper cell culture channel outlet in the stretch system was set at 80 beats $/ \mathrm{min}$, the same frequency as the heartbeat of the patient. (c) Photograph of a cross-section of the microdevice. The upper channel was $1 \mathrm{~mm}$ wide and the lower channel was $2 \mathrm{~mm}$ wide. (d) A cross-sectional image of the channels reconstituted from a confocal microscope image. The extension ratio of the PDMS membrane was estimated at $30 \%$.

\subsection{Analysis of Stretching Properties of the PDMS Membrane}

To confirm cyclic stretch at the heartbeat rate, the liquid flow profile at the upper cell culture channel outlet was measured with a SLG1430-025 liquid flow meter and its data analysis tool, Flow Viewer ASF 1430/ASL1430 (Sensirion, Stäfa, Switzerland). The TYGON tube at the outlet of the upper channel was connected to the liquid flow meter via the PTFE tube $(0.46 \mathrm{~mm}$ id, $0.92 \mathrm{~mm}$ od).

Next, fluorescent microscopic measurement was performed to estimate the travel distance of the PDMS membrane. Fluorescent microbeads (Fluoresbrite Plain YG 10.0 Microspheres, PolyScience, Warrington, PA, USA) were introduced into the upper microchannel. A fluorescent microscope, IX83 (Olympus), with a dichroic mirror block, U-MNIBA3 (excitation 470-495 nm, emission 510-550 nm), was focused on the fluorescent microbeads adsorbed on a surface of the PDMS membrane. Membrane Z-axis positions were measured before and after vacuum application in the lower channel. The distance between the two positions was calculated as a PDMS membrane travel distance.

$3 \mathrm{D}$ reconstruction images based on confocal microscopic measurements were also obtained. Sodium fluorescein (10 $\mu \mathrm{M}$; Wako Pure Chemical, Osaka, Japan) was introduced into the upper microchannel. Z-stack images were obtained with a confocal microscope, FV-1200 (Olympus), and a $473 \mathrm{~nm}$ laser before and after the vacuum. The bottom length of the upper channel was 
measured from the 3D reconstruction image. The ratio of the length after the vacuum to that before the vacuum was calculated as an PDMS membrane extension ratio.

\subsection{Microfluidic Cell Culture}

Normal human PASMCs (single donor, passage 3-10) were purchased from Lonza (Basel, Switzerland), and patient PASMCs (passage 10) were isolated from a patient with idiopathic PAH after obtaining informed consent. These experiments were approved by the ethics committee (National Hospital Organization Okayama Medical Center). Cells were grown with Dulbecco's Modified Eagle's Medium (low glucose; Wako Pure Chemical), supplemented with $10 \%$ fetal bovine serum (Corning, Corning City, NY, USA) and 1\% Antibiotic-Antimycotic (Gibco, Thermo Fisher Scientific, Waltham, MA, USA) in a $25 \mathrm{~cm}^{2}$ CellBIND surface cell culture flask (Corning) until they were approximately $80 \%$ confluent. A $1.5 \times 10^{6}$ cells $/ \mathrm{mL}$ cell suspension was prepared for microfluidic culture.

The upper microchannel was coated by incubation with $0.1 \mathrm{mg} / \mathrm{mL}$ fibronectin (Wako Pure Chemical) at $4{ }^{\circ} \mathrm{C}$ for $16 \mathrm{~h}$, followed by $1 \mathrm{~h}$ at $37^{\circ} \mathrm{C}$. After washing with fresh medium, $30 \mu \mathrm{L}$ of the cell suspension was introduced into the microchannel. The device was wrapped with a wet, lint-free wiper (BEMCOT M-1, Asahi Kasei, Tokyo, Japan) to prevent desiccation, and incubated under static conditions for $24 \mathrm{~h}$ in a $5 \% \mathrm{CO}_{2}$ incubator at $37^{\circ} \mathrm{C}$. After the incubation, the cells were cultured under cyclic stretch or static conditions. Medium exchange was performed every $24 \mathrm{~h}$.

\subsection{Cell Staining}

Cells were stained to visualize f-actin and nucleus. Cells were washed with $100 \mu \mathrm{L}$ phosphate buffered saline with Calcium and Magnesium (PBS(+)), fixed with $50 \mu \mathrm{L}$ paraformaldehyde $(4 \%)$ for $20 \mathrm{~min}$ at $23^{\circ} \mathrm{C}$, and rinsed three times with $100 \mu \mathrm{L}$ PBS(+) for 2 min each. Next, the cells were treated with $50 \mu \mathrm{L}$ rhodamine phalloidin (330 $\mathrm{nM}$ in PBS(+) with $0.1 \%$ Triton X-100; Thermo Fisher Scientific) for $30 \mathrm{~min}$ at $23{ }^{\circ} \mathrm{C}$. The cells were then rinsed three times with $100 \mu \mathrm{L}$ PBS(+) for 2 min each, and treated with $50 \mu \mathrm{L}$ Hoechst $33342(10 \mu \mathrm{g} / \mathrm{mL}$ in PBS(+); Thermo Fisher Scientific). The cells were then rinsed with $100 \mu \mathrm{L}$ PBS(+) three times for 2 min each.

Fluorescence images were obtained using a microscope (IX71 or IX83, Olympus) equipped with a $100 \mathrm{~W}$ high-pressure mercury lamp and a cooled CCD camera, ORCA-R2 (Hamamatsu Photonics, Hamamatsu, Japan). For the observation of rhodamine phalloidin, a dichroic mirror block U-MWIG3 (excitation $530-550 \mathrm{~nm}$, emission $>575 \mathrm{~nm}$ ) was used. Hoecht33342-stained nuclei were visualized using a dichroic mirror block U-MNUA2 (excitation at 360-370 nm, emission at 420-460 nm).

\subsection{RNA Extraction, cDNA Synthesis, and Real-Time PCR}

RNA was extracted from cells collected from the microchannel. Cells cultured in the microchannel were washed three times with $30 \mu \mathrm{L}$ PBS(-). Next, $50 \mu \mathrm{L}$ TrypLE Express (Thermo Fisher Scientific) was added to the microchannel and incubated for $5 \mathrm{~min}$ at $37^{\circ} \mathrm{C}$ in a $\mathrm{CO}_{2}$ incubator. Once all of the cells detached, $100 \mu \mathrm{L}$ of serum containing medium was forcefully added from the inlet of the upper channel with a pipette to push the cells out. The cell suspension was collected from the outlet of the upper channel in a $1.5 \mathrm{~mL}$ microtube.

RNA extraction and cDNA synthesis were performed using an RNA extraction kit, SuperPrep Cell Lysis \& RT Kit for qPCR (Toyobo, Osaka, Japan) for normal cells, or ReliaPrep RNA Miniprep System (Promega, WI, USA) and ReverTra Ace $\alpha$ (Toyobo) for patient PASMCs using standard protocols. Normal cells $\left(1.0 \times 10^{4}\right.$ cells $)$ collected from two microchannels were used for a single reaction, and patient cells $\left(1.0 \times 10^{4}\right.$ cells $)$ collected from four microchannels were used for a single reaction.

Real-time PCR was performed under standard protocols, using the THUNDERBIRD SYBR qPCR Mix (Toyobo) and the following primers: HPRT1 forward, TTTGCTTTCCTTGGTCAGGC; HPRT1 reverse, GCTTGCGACCTTGACCATCT; CyclinD1 forward, CTGGAGGTCTGCGAGGAACA; Cyclin D1 reverse, TGCAGGCGGCTCTTTTTC; VEGF-A (vascular endothelial growth factor A) forward, AGACGGACAGAAAGACAG; VEGF-A reverse, AAGCAGGTGAGAGTAAGC; 21 forward, 
GCGGCAGACCAGCATGA; p21 reverse, GGATTAGGGCTTCCTCTTGGAG. The reaction mixture $(5 \mu \mathrm{L})$ containing forward and reverse primers (final concentration of $300 \mathrm{nM}$ each) and the SYBR Master was mixed with $5 \mu \mathrm{L}$ cDNA. The PCR conditions were as follows: $95^{\circ} \mathrm{C}$ for $10 \mathrm{~min}$, followed by 40 cycles of $95^{\circ} \mathrm{C}$ for $15 \mathrm{~s}$ and $60{ }^{\circ} \mathrm{C}$ for $1 \mathrm{~min}$.

\section{Results and Discussion}

\subsection{Microdevice}

The PDMS membrane was fabricated by spin coating using a $76 \mathrm{~mm} \times 52 \mathrm{~mm}$ PMMA substrate (Figure 1a). The PDMS membrane was easily peeled from the PMMA substrate, and membrane manufacturing yield was as high as $94 \%$. The PDMS sheets and the membrane were laminated (Figure 1b), and a photograph of the obtained microdevice is shown in Figure 1c. Because the surface of the PMMA substrate was flat enough to make a smooth PDMS membrane, a clear phase contrast image of normal cells was obtained (Figure 1d).

\subsection{Stretching Properties of the PDMS Membrane}

The device setup and the principle of PDMS membrane stretching are shown in Figure 2a. The PDMS membrane was stretched by vacuum in the lower control channel, to draw the membrane toward the lower channel. The solenoid valve, connected between the outlet of the lower channel and a vacuum pump, was controlled with LabVIEW software at 80 cycles $/ \mathrm{min}$. The water flow profile at the outlet of the upper cell culture channel was monitored with a flow meter. The obtained flow profile showed the same frequency as that of the valve control (Figure 2b). Breakage of the membrane was not observed during $72 \mathrm{~h}$ cyclic stretch.

To analyze the movement of the membrane, fluorescent microbeads adsorbed on the PDMS membrane surface were monitored with a fluorescent microscope. The distance between two positions, i.e., before and after the vacuum, was $500 \mu \mathrm{m}$, which was the same as the depth of the lower channel. The membrane moved with the vacuum, switching at 80 beats $/ \mathrm{min}$, and the $Z$ axis position of the membrane returned to the initial position every time, i.e., the membrane retained sufficient elasticity. To optimize the PDMS membrane properties, the PDMS prepolymer mixing ratio and curing agent were investigated. Those with mixing ratios of 10:1, 15:1, and 20:1 showed similar properties in motion. Therefore, the PDMS mixture of 10:1 was used for the membrane and is the same concentration as the bulk of the PDMS device.

A cross-section of the PDMS membrane between the upper and lower channels is shown (Figure 2c). Each channel depth was approximately $500 \mu \mathrm{m}$. A cross-sectional fluorescent image shows the upper channel, containing a fluorescein solution in green, and the membrane just below the upper channel (Figure 2d). When the lower control channel was vacuumed, the fluorescein solution moved downward and the membrane drew an arc, shown as a red dashed line (Figure $2 \mathrm{~d}$ ). The length of the red line was measured and the extension ratio was calculated, showing that the PDMS membrane extended approximately $30 \%$.

\subsection{Stretch Culture}

Fluorescent cell images before and after the stretch culture, and the analysis results, are shown in Figure 3. The timeline of the cell stretch experiments is shown in Figure 3a. Cellular alignment and its orientation were quantitatively analyzed from photographs of the cells, as shown in Figure $3 \mathrm{~b}$. The cell alignment angle was defined as the angle between the long axis of a nucleus, considered as elliptical, and the long axis of the microchannel direction. One hundred nuclei were analyzed. Alignment angles were then categorized in $10^{\circ}$ increments.

Photographs of f-actin-stained normal cells are shown Figure 3c. Cells cultured under static conditions were arranged in a random orientation, while the long axes of cells cultured under stretching conditions were aligned perpendicular to the stretch vector. The cell shape was more enlarged after 
$48 \mathrm{~h}$ stretch than $24 \mathrm{~h}$ stretch. These results are consistent with those of a previous report on cyclic stretch-induced cell alignment [25]. Histograms of cellular alignment angles after $24 \mathrm{~h}$ stretch are shown in Figure 3d. All normal cells $(n=100)$ were aligned within 10 degrees of the channel axis.

Photographs of f-actin-stained patient cells are shown in Figure 3e. Patient cells proliferated faster than normal cells, and reached in an overconfluent state after $24 \mathrm{~h}$ cyclic stretch culture, so we stopped culturing at that time. The long axes of patient cells cultured under stretch conditions were aligned perpendicular to the stretch vector. Histograms of cellular alignment angles after $24 \mathrm{~h}$ stretch are shown in Figure 3f. Unlike normal cells, patient cells aligned within 10 degrees of the channel axis were approximately $40 \%$. The response of the patient cells to stretching stress was different from that of normal cells. In both stretch and static cases, the cell density of patient cells was higher than that of normal cells. It has been established that in vivo, SMCs align parallel to stretch along the circumferential direction of vessels, and this parallel alignment has been replicated in vitro in $3 \mathrm{D}$ cultures [26]. In our case, patient cells grew to a high density and partially piled up on the monolayer, thereby forming the 3D structure. This might help recreate a closer in vivo cell environment for cell alignment to be parallel to stretch.

a

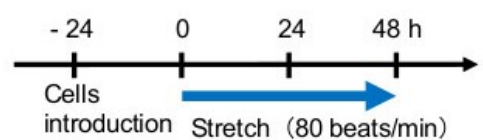

C Normal cells

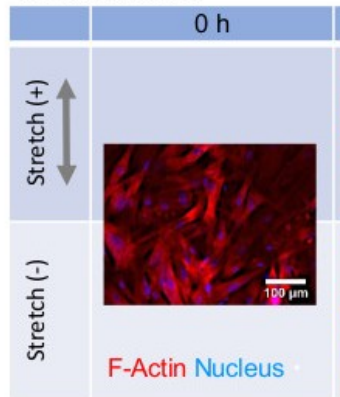

e

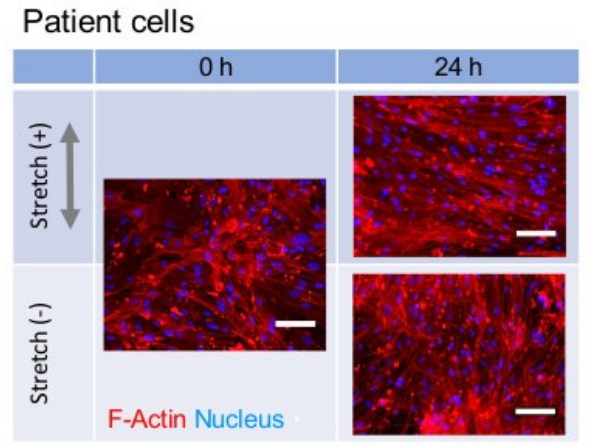

b

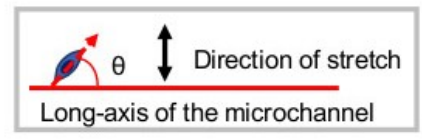

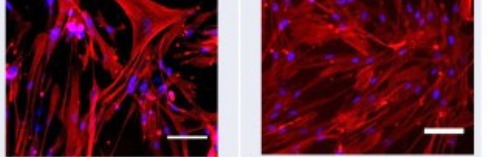
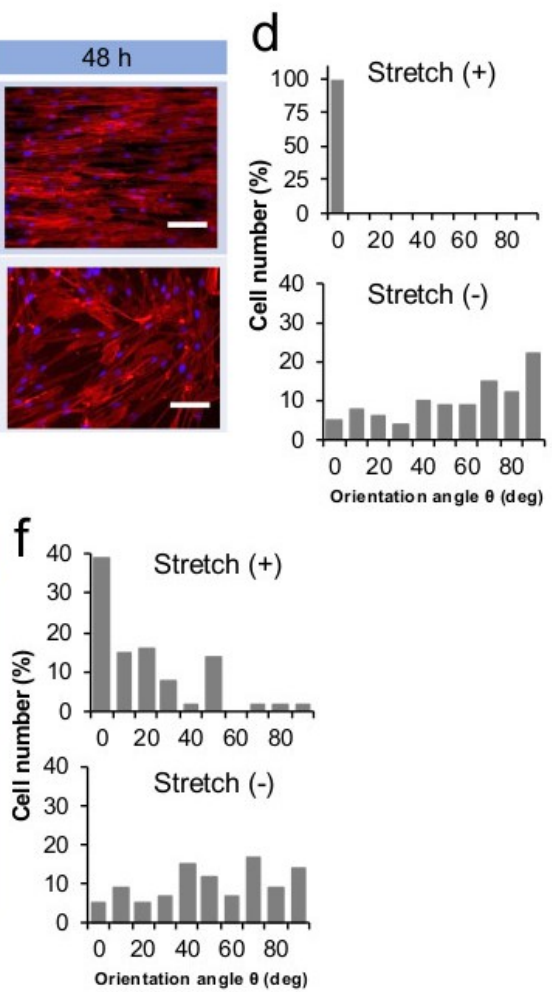

Figure 3. Effects of cyclic stretch on cell alignment. (a) Timeline of the cell stretch experiments. (b) Cell orientation was analyzed by measuring the orientation angle between the long axis of the cell nucleus and the microchannel. (c) Normal cells were stained for f-actin with rhodamine-phalloidin (red) and the nucleus was stained with Hoechst 33342 (blue). Cyclic stretch caused cells to align perpendicular to the stretch vector. (d) Distribution of the orientation angle in normal cells is shown in histograms (100 cells, 24 h). (e) Patient cells were stained as in (c). (f) Distribution of the orientation angle in patient cells is shown in histograms (100 cells, $24 \mathrm{~h}$ ). 


\subsection{Cell Proliferation}

Cell densities of normal and patient cells are shown Figure 4a. Both cell types showed different proliferation rates under static conditions. Both cells were seeded at the same cell density, but after $24 \mathrm{~h}$ culture $(0 \mathrm{~h}$ in Figure $4 \mathrm{a})$ the patient cell density was $5.3 \times 10^{4}$ cells $/ \mathrm{cm}^{2}$, which was 1.9 -fold greater than that of normal cells. These results indicate that, compared to normal cells, proliferation might be enhanced in the patient cells, and that this cell proliferation in microchannels was similar to that in conventional dishes, as suggested in our previous reports $[27,28]$.

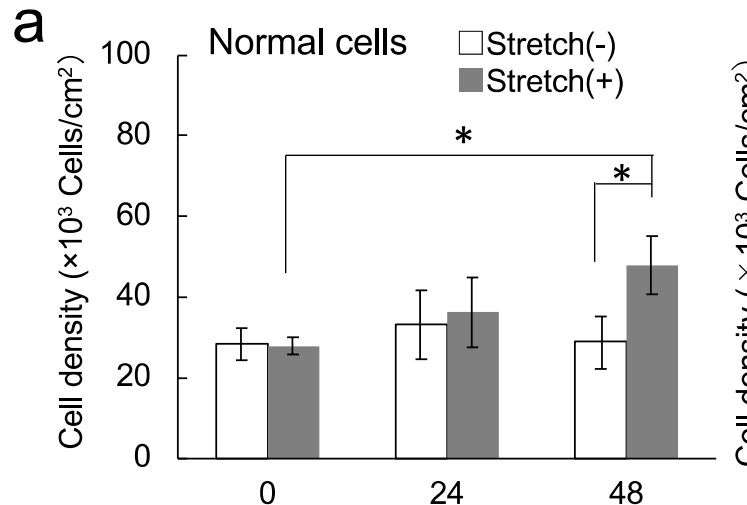

b
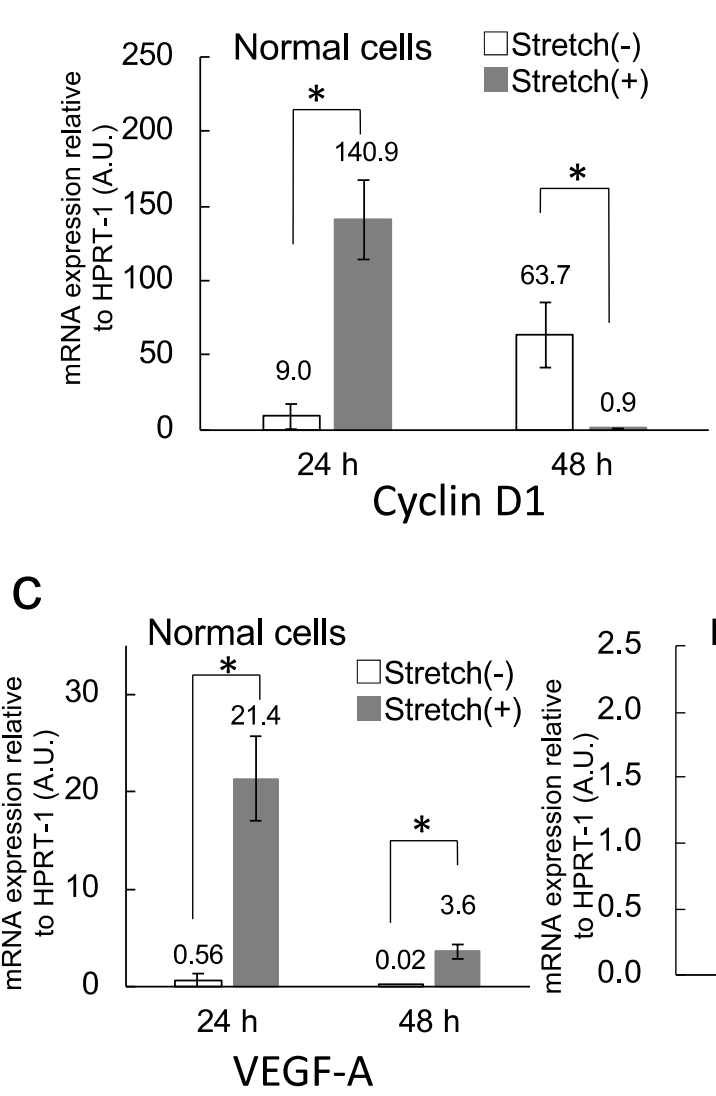
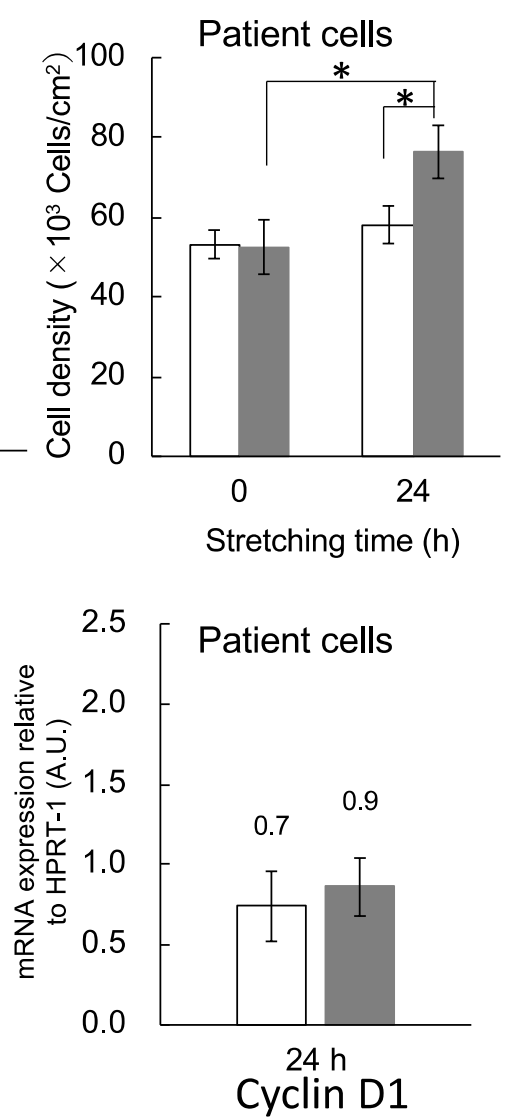
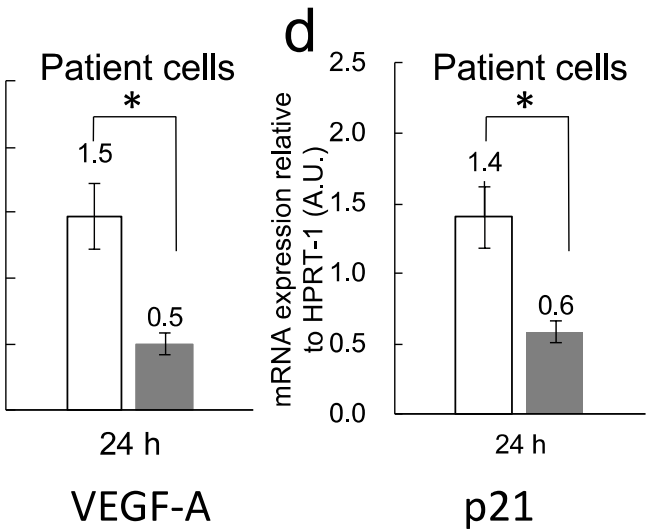

Figure 4. Effects of cyclic stretch on cell proliferation. (a) Cell proliferation. Data are shown as mean \pm standard deviation (SD) of three images $(500 \mu \mathrm{m} \times 500 \mu \mathrm{m}) .{ }^{*} p<0.05$ (unpaired two-tailed Student's $t$ test). Gene transcription of (b) Cyclin D1, (c) VEGF-A, and (d) $p 21$ in cells cultured in the microchannel. mRNA levels were quantified by real-time PCR. HPRT1 was used as a control gene. Data are shown as means $\pm \mathrm{SD}(n=3)$. 
Under static conditions, normal cells maintained density at $3.0 \times 10^{4}$ cells $/ \mathrm{cm}^{2}$. However, they propagated to $4.8 \times 10^{4}$ cells $/ \mathrm{cm}^{2}$ after the $48 \mathrm{~h}$ stretch culture. The patient cells also increased to $7.6 \times 10^{4}$ cells $/ \mathrm{cm}^{2}$ under the stretching conditions. Therefore, the stretching stimulation might enhance cell proliferation. Mechanical stretch may change the conformation of cell membrane molecules resulting from the interaction between extracellular matrix proteins and their integrin receptors; it might activate intracellular signaling pathways. To our knowledge, this is the first report showing that patient cells increase by stretching stress. These results are consistent with the abnormal proliferation observed in PAH. In this experiment, stretching stress was applied to the cells without increasing pressure inside the microchannel. A previous report applied both high pressure and stretch stress to the cells [14]. Our data suggest that stretch stress in and of itself promotes cell proliferation in PAH.

\subsection{Transcription Analysis}

Cyclin D1 and VEGF-A transcription levels in cells cultured in the microfluidic device for 24 or $48 \mathrm{~h}$ under stretching conditions were analyzed. Cyclin D1 is a protein involved in the regulation of cell cycle progression [29], and VEGF-A is a member of the PDGF/VEGF growth factor family [30]. $V E G F-A$ is an endothelial-specific growth factor and it plays an important role in formation of blood vessels, so we analyzed VEGF-A expression together with Cyclin D1. In normal cells cultured for $24 \mathrm{~h}$ under the stretching conditions, Cyclin D1/HPRT1 and VEGF-A/HPRT1 ratios showed a significant increase compared with those of the static-cultured cells (Figure $4 \mathrm{~b}, \mathrm{c}$ ). Stretch stress promoted the transcription of Cyclin D1 and VEGF-A in normal cells, suggesting that cell proliferation was promoted in these cells.

However, the difference between $V E G F-A$ transcription levels in normal cells cultured under static and stretching conditions was reduced after $48 \mathrm{~h}$ culture (Figure $4 \mathrm{c}$ ). Quinn et al. showed that $V E G F-A$ transcription levels in ovine pulmonary artery vascular smooth muscle cells peaked at $24 \mathrm{~h}$ under cyclic stretch conditions, and declined toward control levels at $48 \mathrm{~h}$ [31]. Our results agreed with this report.

Moreover, Cyclin D1 transcription levels under the stretching conditions were lower than those under static conditions (Figure 4b). As shown in Figure 3, the short axes of the cells were elongated by stretch at this time, so the cell extension was small, and the cells were minimally affected by the stretching stress. Therefore, VEGF-A and Cyclin D1 transcription levels might not be increased. In contrast, normal cells cultured under static conditions were in growth at that time, because their growth was slow. Therefore, the transcription level of Cyclin D1 at $48 \mathrm{~h}$ was higher in these cells than it was at $24 \mathrm{~h}$.

On the other hand, patient cells after $24 \mathrm{~h}$ of culture under static and stretching conditions expressed Cyclin D1 at similar levels, and VEGF-A transcription levels under the stretching conditions were slightly lower than those under static conditions (Figure 4c). We assume that patient cell proliferation was faster than that of normal cells, and that there was little difference in transcript levels of Cyclin D1 and VEGF-A among samples with or without stretching stress. However, transcription levels of p21, a key cell cycle regulator that arrests cells in the G1 and G2 phases [32], under the stretching conditions was lower than that under static conditions (Figure $4 \mathrm{~d}$ ). These results were concordant with cell proliferation results (Figure 4a).

\section{Conclusions}

A microfluidic cell stretch device was developed to investigate the effects of stretching stress on PASMCs in PAH. In the device, a cell culture PDMS substrate was extended by $30 \%$ at the patient heartbeat frequency. While there are many reports investigating the effects of stretch on the same plane, there are few reports on the effects of circumferential stretch. To mimic the artery, it is important to use a device which can expose cells to cyclic circumferential stretch. The proliferation of normal and patient cells was enhanced by the circumferential stretching stimulation. This is the first report 
showing behavior of patient cells under stretching conditions. These results are consistent with the observed abnormal proliferation in PAH. Using this device, circumferential stretch stress was applied to cells without increasing internal microchannel pressure. Our data suggests that stretch stress itself promotes cell proliferation in PAH. Further studies are needed to investigate in detail the effects of stretching frequency, and those of long-time stimulation, on cell proliferation. These effects will also need to be compared with pressure-induced cell stretching effects. Our device can connect to a pressure-driven flow controller that generates pulsating blood flow, and might help elucidate the mechanisms underlying the effects observed in PAH.

Author Contributions: Conceived and designed the experiments: K.S., A.O. Performed the experiments: M.N., A.O. Analyzed the data: M.N., A.O., K.S. Wrote the paper: M.N., K.S.

Funding: This study was supported in part by Banyu Foundation Research Grant (to K.S.), Shiseido Female Researcher Science Grant (to K.S.), Koyanagi Foundation Research Grant (to K.S.), GSK Japan Research Grant (to A.O.), and a Grant-in-Aid for Scientific Research (JSPS, KAKENHI; Grant Numbers 16H04170 to K.S., 16 KK0116 to K.S., and 16K09488 to A.O.).

Conflicts of Interest: The authors declare no conflict of interest.

\section{References}

1. Vonk Noordegraaf, A.; Groeneveldt, J.A.; Bogaard, H.J. Pulmonary hypertension. Eur. Respir. Rev. 2016, 25, 4-11. [CrossRef] [PubMed]

2. Maarman, G.; Lecour, S.; Butrous, G.; Thienemann, F.; Sliwa, K. A comprehensive review: The evolution of animal models in pulmonary hypertension research; are we there yet? Pulm. Circ. 2013, 3, 739-756. [CrossRef] [PubMed]

3. Ogawa, A.; Firth, A.L.; Yao, W.; Madani, M.M.; Kerr, K.M.; Auger, W.R.; Jamieson, S.W.; Thistlethwaite, P.A.; Yuan, J.X. Inhibition of mTOR attenuates store-operated $\mathrm{Ca}^{2+}$ entry in cells from endarterectomized tissues of patients with chronic thromboembolic pulmonary hypertension. Am. J. Physiol. Lung Cell. Mol. Physiol. 2009, 297, L666-L676. [CrossRef] [PubMed]

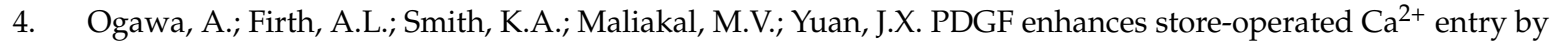
upregulating STIM1/Orai1 via activation of Akt/mTOR in human pulmonary arterial smooth muscle cells. Am. J. Physiol. Cell Physiol. 2012, 302, C405-C411. [CrossRef] [PubMed]

5. Ogawa, A.; Firth, A.L.; Ariyasu, S.; Yamadori, I.; Matsubara, H.; Song, S.; Fraidenburg, D.R.; Yuan, J.X. Thrombin-mediated activation of Akt signaling contributes to pulmonary vascular remodeling in pulmonary hypertension. Physiol. Rep. 2013, 1, e00190. [CrossRef]

6. Sasaki, N.; Shinjo, M.; Hirakawa, S.; Nishinaka, M.; Tanaka, Y.; Mawatari, K.; Kitamori, T.; Sato, K. A palmtop-sized microfluidic cell culture system driven by a miniaturized infusion pump. Electrophoresis 2012, 33, 1729-1735. [CrossRef] [PubMed]

7. Sato, K.; Sasaki, N.; Svahn, H.A.; Sato, K. Microfluidics for nano-pathophysiology. Adv. Drug Deliv. Rev. 2014, 74, 115-121. [CrossRef] [PubMed]

8. Sato, M.; Sasaki, N.; Ato, M.; Hirakawa, S.; Sato, K.; Sato, K. Microcirculation-on-a-chip: A microfluidic platform for assaying blood- and lymphatic-vessel permeability. PLoS ONE 2015, 10, e0137301. [CrossRef] [PubMed]

9. Sato, K.; Sato, K. Recent Progress in the Development of Microfluidic Vascular Models. Anal. Sci. 2018, 34, 755-764. [CrossRef]

10. Tazawa, H.; Sunaoshi, S.; Tokeshi, M.; Kitamori, T.; Ohtani-Kaneko, R. An easy-to-use polystyrene microchip-based cell culture system. Anal. Sci. 2016, 32, 349-353. [CrossRef] [PubMed]

11. Ohtani-Kaneko, R.; Sato, K.; Tsutiya, A.; Nakagawa, Y.; Hashizume, K.; Tazawa, H. Characterisation of human induced pluripotent stem cell-derived endothelial cells under shear stress using an easy-to-use microfluidic cell culture system. Biomed. Microdevices 2017, 19, 91. [CrossRef] [PubMed]

12. Cochrane, A.; Albers, H.J.; Passier, R.; Mummery, C.L.; van den Berg, A.; Orlova, V.V.; van der Meer, A.D. Advanced in vitro models of vascular biology: Human induced pluripotent stem cells and organ-on-chip technology. Adv. Drug Deliv. Rev. 2018. [CrossRef] [PubMed] 
13. Gray, K.M.; Stroka, K.M. Vascular endothelial cell mechanosensing: New insights gained from biomimetic microfluidic models. Semin. Cell Dev. Biol. 2017, 71, 106-117. [CrossRef] [PubMed]

14. Zhou, J.; Niklason, L.E. Microfluidic artificial "vessels" for dynamic mechanical stimulation of mesenchymal stem cells. Integr. Biol. 2012, 4, 1487-1497. [CrossRef] [PubMed]

15. Zheng, W.; Jiang, B.; Wang, D.; Zhang, W.; Wang, Z.; Jiang, X. A microfluidic flow-stretch chip for investigating blood vessel biomechanics. Lab Chip 2012, 12, 3441-3450. [CrossRef] [PubMed]

16. Huang, R.; Zheng, W.; Liu, W.; Zhang, W.; Long, Y.; Jiang, X. Investigation of tumor cell behaviors on a vascular microenvironment-mimicking microfluidic chip. Sci. Rep. 2015, 5, 17768. [CrossRef]

17. Van Engeland, N.C.A.; Pollet, A.; den Toonder, J.M.J.; Bouten, C.V.C.; Stassen, O.; Sahlgren, C.M. A biomimetic microfluidic model to study signalling between endothelial and vascular smooth muscle cells under hemodynamic conditions. Lab Chip 2018, 18, 1607-1620. [CrossRef]

18. Yasotharan, S.; Pinto, S.; Sled, J.G.; Bolz, S.S.; Gunther, A. Artery-on-a-chip platform for automated, multimodal assessment of cerebral blood vessel structure and function. Lab Chip 2015, 15, 2660-2669. [CrossRef]

19. Sato, K.; Nakajima, M.; Tokuda, S.; Ogawa, A. Fluidic culture and analysis of pulmonary artery smooth muscle cells for the study of pulmonary hypertension. Anal. Sci. 2016, 32, 1217-1221. [CrossRef]

20. Ogawa, A.; Satoh, T.; Tamura, Y.; Fukuda, K.; Matsubara, H. Survival of Japanese patients with idiopathic/heritable pulmonary arterial hypertension. Am. J. Cardiol. 2017, 119, 1479-1484. [CrossRef]

21. Mata-Greenwood, E.; Grobe, A.; Kumar, S.; Noskina, Y.; Black, S.M. Cyclic stretch increases VEGF expression in pulmonary arterial smooth muscle cells via TGF- $\beta 1$ and reactive oxygen species: A requirement for NADPH oxidase. Am. J. Physiol. Lung Cell. Mol. Physiol. 2005, 289, L288-L289. [CrossRef]

22. Chang, H.; Shyu, K.G.; Wang, B.W.; Kuan, P. Regulation of hypoxia-inducible factor- $1 \alpha$ by cyclical mechanical stretch in rat vascular smooth muscle cells. Clin. Sci. 2003, 105, 447-456. [CrossRef] [PubMed]

23. Ishigaki, Y.; Sato, K. Effects of microchannel shape and ultrasonic mixing on microfluidic padlock probe rolling circle amplification (RCA) reactions. Micromachines 2018, 9, 272. [CrossRef] [PubMed]

24. Sato, K.; Sato, M.; Yokoyama, M.; Hirai, M.; Furuta, A. Influence of culture conditions on cell proliferation in a microfluidic channel. Anal. Sci. 2018. [CrossRef]

25. Standley, P.R.; Cammarata, A.; Nolan, B.P.; Purgason, C.T.; Stanley, M.A. Cyclic stretch induces vascular smooth muscle cell alignment via NO signaling. Am. J. Physiol. Heart Circ. Physiol. 2002, 283, H1907-H1914. [CrossRef]

26. Bono, N.; Pezzoli, D.; Levesque, L.; Loy, C.; Candiani, G.; Fiore, G.B.; Mantovani, D. Unraveling the role of mechanical stimulation on smooth muscle cells: A comparative study between 2D and 3D models. Biotechnol. Bioeng. 2016, 113, 2254-2263. [CrossRef] [PubMed]

27. Ogawa, A.; Nakamura, K.; Matsubara, H.; Fujio, H.; Ikeda, T.; Kobayashi, K.; Miyazaki, I.; Asanuma, M.; Miyaji, K.; Miura, D.; et al. Prednisolone inhibits proliferation of cultured pulmonary artery smooth muscle cells of patients with idiopathic pulmonary arterial hypertension. Circulation 2005, 112, 1806-1812. [CrossRef]

28. Fujio, H.; Nakamura, K.; Matsubara, H.; Kusano, K.F.; Miyaji, K.; Nagase, S.; Ikeda, T.; Ogawa, A.; Ohta-Ogo, K.; Miura, D.; et al. Carvedilol inhibits proliferation of cultured pulmonary artery smooth muscle cells of patients with idiopathic pulmonary arterial hypertension. J. Cardiovasc. Pharmacol. 2006, 47, 250-255. [CrossRef]

29. Sherr, C.J. D-type cyclins. Trends Biochem. Sci. 1995, 20, 187-190. [CrossRef]

30. Holmes, D.I.; Zachary, I. The vascular endothelial growth factor (VEGF) family: Angiogenic factors in health and disease. Genome Biol. 2005, 6, 209. [CrossRef]

31. Quinn, T.P.; Schlueter, M.; Soifer, S.J.; Gutierrez, J.A. Cyclic mechanical stretch induces VEGF and FGF-2 expression in pulmonary vascular smooth muscle cells. Am. J. Physiol. Lung Cell. Mol. Physiol. 2002, 282, L897-L903. [CrossRef] [PubMed]

32. Chen, A.; Huang, X.; Xue, Z.; Cao, D.; Huang, K.; Chen, J.; Pan, Y.; Gao, Y. The role of p21 in apoptosis, proliferation, cell cycle arrest, and antioxidant activity in UVB-irradiated human HaCaT keratinocytes. Med. Sci. Monit. Basic Res. 2015, 21, 86-95. [CrossRef] [PubMed]

(C) 2018 by the authors. Licensee MDPI, Basel, Switzerland. This article is an open access article distributed under the terms and conditions of the Creative Commons Attribution (CC BY) license (http://creativecommons.org/licenses/by/4.0/). 